\title{
A Multivariate Poisson Model of Consumer Choice in a Multi-Airport Region
}

\author{
Andrew J. BUCK*, Erwin A. BLACKSTONE, Simon HAKIM
}

Department of Economics, Temple University, Philadelphia, USA;

*Corresponding Author.

Email: buck@temple.edu

Received August 30, 2009; revised October 3, 2009; accepted November 17, 2009

\begin{abstract}
Using the results of a unique telephone survey the frequency of consumer flights from airports in a multi-airport region are modeled using a multivariate Poisson framework, the parameters of which were estimated using a latent variable application of the expectation maximization algorithm. This offers a different perspective since other work on airport choice uses the results of airport intercept surveys that capture only a single choice per respondent, whereas the data from the phone survey is count data for the airports in the study. An airport's own-distance had the expected negative impact on mean usage of the airport, although the cross effects were somewhat mixed. Ticket price differences between airports were not always statistically significant. Mean usage was found to be increasing in income for PHL, but was decreasing for the other airports, reflecting the increasing value of respondents' time as their income rises. If the destination of flights is domestic (international) then the result is to increase usage of PHL, BWI and EWR (JFK). Except for JFK, if the purpose of travel is mostly pleasure then it results in more travel from JFK and less from the other three airports. The availability of a low cost carrier would result in more frequent travel.
\end{abstract}

Keywords: Airport Choice, Poisson Regression, Expectation Maximization

\section{Introduction}

Using the results of a unique telephone survey the frequency of consumer flights from airports in a multi-airport region are modeled using a multivariate Poisson framework. This offers a different perspective from previous research in two important ways. First, other work on airport choice uses the results of airport intercept surveys that capture only a single choice per respondent, whereas the data from the phone survey used in this paper is count data for the four airports in the study. Second, models based on intercept surveys uniformly use binary choice models such as either probit or logit methods to estimate the model parameters of the mutually exclusive choices [1-3]. The consumers in the present study are observed to choose from among four airports on a repeated basis, resulting in a n-tuple of count data.

Modeling count data requires use of Poisson or negative binomial specifications. The present study expands the usual statistical count model to the appropriaten-tuple count model in the form of the multivariate Poisson so that the counts can have non-zero covariances. The fundamental difference between earlier work and that presented here is the difference between allocation modeling and modeling at the extensive margin. Until recently the use of multivariate Poisson regression was not an option [4]. An expectation maximization algorithm is used to estimate the parameters of a multivariate Poisson model of consumer decisions.

Until 1983 the Civil Aeronautics Board (CAB) was responsible for regulating airfares in the United States. As a consequence of that regulation commercial passenger carriers competed on many dimensions other than price. Such behavior was recognized as being economically inefficient: the price system was not being allowed to direct resources to their greatest value in use. The $\mathrm{CAB}$ was dismantled on the premise that price competition among carriers would benefit consumers and direct productive resources to their greatest value in use. It was felt that, inter alia, the threat of entry would be sufficient to prevent airlines from being able to exploit apparent monopoly power. That premise ignores the fact that consumers are an essential element in the exercise of market power. If consumers do not search for low fares or fare differences are unimportant, then it is unlikely that the threat of entry will have much impact on the fare structure: The effect of the entry of a low fare carrier will only be the reallocation of fliers among carriers at an 
airport, with little impact on the allocation of passengers among airports. Indeed, one of the current stylized facts about air travel is that there is more variation in price among carriers at an airport than among airports. It is possible to evaluate the effect of low fares on consumer behavior, and by implication the likely success of the threat of entry as a disciplinary device, by examining multi-airport markets. The unwillingness of flyers to travel to other airports to obtain lower fares increases the ability of carriers to exploit monopoly power and discriminate in prices ${ }^{1}$. Since broad geographic markets are often used in merger cases ${ }^{2}$ our analysis may shed some light on such markets.

Heretofore airport choice studies have focused on the choice of airport for a particular trip using intercept surveys of travelers in the chosen airport. Ashford and Benchemam [5] studied airport choice in central England for the period 1975-1978. Among business travelers distance to the airport was the most important variable, followed by frequency of service. Fare was found to be most important among those traveling for pleasure. Caves et al. [6] found that access time, frequency and fare to be significant variables in a model of choice between mature and emerging airports in England. Thompson and Caves [7] used data for 1983 to study airport choice in northern England. For both business and leisure travelers distance to the airport and number of available seats were important. Frequency of service was also important for business travelers. In the San Francisco market Harvey [8] found access time and frequency of service to be determinative. None of these earlier efforts would lead one to believe that the difference in fares from different airports would lead to more competition among carriers, or that fare differences could lead to the reallocation of market share among airports. More recent studies, using various modifications of the multinomial logit model also confirm the importance of access time and frequency of flights in airport choice [9-13]. Interestingly, cost was also of secondary interest in the choice of airport by air freight carriers [14]. Gosling [15] offers a comprehensive review of the literature. The lack of searching for the best fare among airports is perhaps understandable given the time cost of travel to a lower fare airport may swamp any differences in fares.

In spring of 2000 a phone survey was conducted of

${ }^{1}$ At the time of our study US Airways garnered at least 60 percent of the business at Philadelphia International Airport, and in 2005 after the entry of low fare carriers they still had $63 \%$ [16]. At sixteen large airports the leading carrier had at least 50 percent of airline departures in 2000 [17].

${ }^{2}$ For example, in hospital merger cases the geographic market has been considered to be as large as 100 miles.

${ }^{3}$ In the sample 827 respondents had traveled outside the region, not necessarily by air, and only those respondents were included in the estimation. A survey research firm conducted the phone interviews. Calls were made, nearly 5000, until there were 1100 complete responses. residents of the market area of Philadelphia International Airport (PHL). The eventual goal of PHL was to learn about its customer base with an eye to increasing its market share in a multi-airport region. PHL management considers its facility in competition with its large neighbors to the north and the south: JFK International, Newark International (EWR) and Baltimore-Washington International (BWI). The relevant market was defined by PHL's management; see Fgure 1 for a map of the market. Newark is the largest of the four and Baltimore-Washington is the smallest.

The 1100 respondents in the final sample ${ }^{3}$ were asked a wide variety of questions about their travel and airport usage. From the survey data both univariate and multivariate Poisson models of airport usage were estimated. A preference for using a low fare airport was expressed by survey participants. A rising fare premium for using PHL resulted in higher mean use for Newark (EWR), Baltimore (BWI) and New York (JFK). The fare premium was also positive for use of PHL, reflecting that market power of PHL's dominant carrier at the time of the survey. The fare coefficients were not always statistically significant. Apparently respondents liked the idea of using a low fare airport but did not base their eventual choice on fare differences. As a new entrant in a multi-airport region, a discount airline should enter at that airport where there is the greatest opportunity for winning market share from incumbents without relying on attracting new passengers from other airports.

Income was a significant variable in the use of the three distant airports: BWI, JFK and EWR. Higher income increased the likelihood of flying from either JFK or BWI in the previous year, but the sign is reversed for BWI. If distance from the respondent's residence to the airport was an important consideration then it increased their likelihood of using any of the airports. The actual distance had the expected own airport effects and cross effects. If the purpose of the trips was predominantly business than respondents were more likely to fly from PHL, BWI, and EWR, but not JFK.

\section{The Model}

The phone survey used to assemble the data asked respondents to think about all of their travel in the prior year. This precluded directly asking about choice of airline as could be done in an intercept interview in an airport. Consequently the model used here addresses only the frequency of having chosen an airport in the prior year, although the respondents were asked about the importance of being able to use their carrier of choice in their selecting an airport.

Over a very short interval of time the decision about which airport to use can be cast as either an index function model or a random utility model $[18,19]$. In the index function approach the agent makes a marginal bene- 
fit-marginal cost calculation based on the utility achieved by choosing to fly from a particular airport between one origin-destination pair instead of another. The difference between benefit and cost is modeled as an unobservable variable $\mathrm{y}^{*}$ such that

$$
y^{*}=x^{\prime} \beta+\varepsilon
$$

The error term is assumed to have a particular known distribution. The net benefit of the choice is never observed, only the choice itself. Therefore the observation is

$$
y= \begin{cases}1 & \text { if } y^{*}>0 \\ 0 & \text { if } y^{*} \leq 0\end{cases}
$$

and $x^{\prime} \beta$ is known as the index function.

The preponderance of airport choice studies rely on intercept interviews in the airports. Consequently the respondent has made an airline and airport choice from among mutually exclusive alternatives in a short interval of time. In this context a multinomial logit or multinomial probit model is appropriate (see the earlier citations).

The individual studies and the methodological approach reviewed above all suppose that in a short time interval the economic agent is choosing from among mutually exclusive alternatives. In the phone survey conducted for the Philadelphia International Airport the respondents were not at a particular airport, having made a travel mode decision. Rather, they were at home and were asked to reflect on all the choices that they had made in the previous year. If the decision to fly from an airport is made a large number of times during the year, with a small probability of flying in each interval then in the limit the observed Bernoulli process

\footnotetext{
${ }^{4}$ Alternative methods for modeling count data are References [21-23] Aitchison and Ho propose the use of a Poisson and log normal mixture to model multivariate count data. The mixture involves a Possion specification of the counts with a multivariate log normal distribution over the Poisson rate parameters. This approach permits negative correlations between the counts, which does no occur in the data used here. Further, their model is more flexible with regard to over dispersion in the marginal distributions. In the data used here the over dispersion is not observed in the joint distribution. Finally, they state that their model cannot describe the variability of multivariate counts with small means and little over dispersion, the case here. Terza and Wilson use a mixed multinomial Poisson process to model event frequencies. Built into their approach is the problem of the independence of irrelevant alternatives and no covariance between choices. Shonkwiler and Englin use a multinomial Dirichlet negative binomial process to model a system of incomplete demands. In their approach the covariance between trip choices must be negative. The procedure used here does not suffer from the independence of irrelevant choices problem but restricts the $\left(\mathrm{Y}_{\mathrm{i}}, \mathrm{Y}_{\mathrm{j}}\right)$ gross covariances to be positive, although covariates can have negative coefficients. All three alternatives to the multivariate Poisson are mixtures. As such, they are in the spirit of Bayesian modeling since one must make a specific assumption about the mixing distribution.
}

of $\left(1^{\prime}\right)$ is a Poisson random variable [20]. Having flown from, say, Newark Airport at least once in the year does not preclude having flown from another airport, perhaps several times, during the same year. Hence, the cost-benefit calculation of (1) is made many times during the year for each of the airports in the region. Since the net benefits of flying from a particular airport a given number of times is unobserved, the observed data on the dependent variable is the quadruplet $\mathrm{y}_{1} \geq 0, \mathrm{y}_{2} \geq 0$, $y_{3} \geq 0, y_{4} \geq 0$. The count data in $y_{1}, y_{2}, y_{3}$, and $y_{4}$ are not independent of one another.

Since the frequency of flying from any one of a choice of airports is by its nature an n-tuple of counts, the appropriate statistical model must be multivariate with non-zero correlations. With this in mind the choice model for the four airports included in the Philadelphia International Airport study of (1) becomes a multivariate Poisson model ${ }^{4}$ derived by Mahamunulu, 1967 and is of the form

$$
P(Y)=\left[\prod_{i}^{4} \varphi\left(y_{i}\right)\right] \sum_{r=0}^{\infty}\left[\frac{1}{r !}\left\{\sum_{i<j}^{4} \mu_{i j} K_{r}\left(y_{i}\right) K_{r}\left(y_{j}\right)\right\}^{r}\right]
$$

where $K_{r}\left(y_{r}\right)=(-1)^{r} \Delta^{r} \varphi\left(y_{i}-r\right) / \varphi\left(y_{i}\right)$ is the Charlier polynomial and $\phi(\mathrm{y})$ is the Poisson probability density function. The problem with the representation in (2) is that it is an infinite series and is therefore not directly empirically implementable.

Fortunately there is a much simpler representation of the multivariate Poisson using unobserved, or latent, variables. With specific reference to the frequency of choosing from among the four airports, consider a vector $X=\left(X_{1}, X_{2}, X_{3}, X_{4}, X_{12}, X_{13}, X_{14}, X_{23}, X_{24}, X_{34}\right)^{T}$ where the $X_{\mathrm{ij}}$ are independent latent random variables and each follows a Poisson distribution. The mean of this vector is then $\theta=\left(\theta_{1}, \theta_{2}, \theta_{3}, \theta_{4}, \theta_{12}, \theta_{13}, \theta_{14}, \theta_{23}, \theta_{24}, \theta_{34}\right)^{T}$. Now define the four element vector of observable frequency of flights from each of the four airports as $Y=A X$ where $\mathrm{A}$ is defined as

$$
A=\left[\begin{array}{llllllllll}
1 & 0 & 0 & 0 & 1 & 1 & 1 & 0 & 0 & 0 \\
0 & 1 & 0 & 0 & 1 & 0 & 0 & 1 & 1 & 0 \\
0 & 0 & 1 & 0 & 0 & 1 & 0 & 1 & 0 & 1 \\
0 & 0 & 0 & 1 & 0 & 0 & 1 & 0 & 1 & 1
\end{array}\right]
$$

Under this specification of the problem each of the $y_{i}$ is the sum of a specific four member subset of ten independent Poisson random variables. That is, the marginal probability function for the random vector $\mathrm{Y}$ can be written as 


$$
\operatorname{Pr}\left[\begin{array}{l}
Y_{1}=y_{1} \\
Y_{2}=y_{2} \\
Y_{3}=y_{3} \\
Y_{4}=y_{4}
\end{array}\right]=\left[\begin{array}{l}
\frac{\exp \left(-\theta_{1}-\theta_{12}-\theta_{13}-\theta_{14}\right)\left(\theta_{1}+\theta_{12}+\theta_{13}+\theta_{14}\right)^{y_{1}}}{y_{1} !} \\
\frac{\exp \left(-\theta_{2}-\theta_{12}-\theta_{23}-\theta_{24}\right)\left(\theta_{2}+\theta_{12}+\theta_{23}+\theta_{24}\right)^{y_{2}}}{y_{2} !} \\
\frac{\exp \left(-\theta_{3}-\theta_{13}-\theta_{23}-\theta_{34}\right)\left(\theta_{3}+\theta_{13}+\theta_{23}+\theta_{34}\right)^{y_{3}}}{y_{3} !} \\
\frac{\exp \left(-\theta_{4}-\theta_{14}-\theta_{24}-\theta_{34}\right)\left(\theta_{4}+\theta_{14}+\theta_{24}+\theta_{34}\right)^{y_{4}}}{y_{4} !}
\end{array}\right]
$$

The mean vector for $\mathrm{Y}$, the frequencies for flying from the four different airports, is given by

$$
\begin{aligned}
& A \theta=\left[\theta_{1}+\theta_{12}+\theta_{13}+\theta_{14} \quad \theta_{2}+\theta_{12}+\theta_{23}+\theta_{24}\right. \\
& \left.\theta_{3}+\theta_{13}+\theta_{23}+\theta_{34} \quad \theta_{4}+\theta_{14}+\theta_{24}+\theta_{34}\right]^{T}
\end{aligned}
$$

The frequencies with which an individual flies from the airports are pair-wise correlated and the covariance matrix for $\mathrm{Y}$ is

$$
\begin{gathered}
A \Sigma \boldsymbol{A}^{T}=\left[\begin{array}{cc}
\theta_{1}+\theta_{12}+\theta_{13}+\theta_{14} & \theta_{12} \\
\theta_{12} & \theta_{2}+\theta_{12}+\theta_{23}+\theta_{24} \\
\theta_{13} & \theta_{23} \\
\theta_{14} & \theta_{24} \\
\theta_{13} & \theta_{14} \\
\theta_{23} & \theta_{24} \\
\theta_{3}+\theta_{13}+\theta_{23}+\theta_{34} & \theta_{34} \\
\theta_{34} & \theta_{4}+\theta_{14}+\theta_{24}+\theta_{34}
\end{array}\right]
\end{gathered}
$$

For estimation of the rate parameters, $\theta$, let the vector $\mathrm{y}_{\mathrm{i}}=\left(\mathrm{y}_{\mathrm{i} 1}, \mathrm{y}_{\mathrm{i} 2}, \mathrm{y}_{\mathrm{i} 3}, \mathrm{y}_{\mathrm{i} 4}\right)^{\prime}, \mathrm{i}=1,2, \ldots, \mathrm{n}$ denote the observations on the frequency of flights from the four airports. To ease the notational burden define the set $S=R_{1} \cup R_{2}$, where $\mathrm{R}_{1}=(1,2,3,4)$ is an index set over the means of the latent Poisson variates unique to each airport and $\mathrm{R}_{2}=(\mathrm{rs}$, with $\mathrm{r}, \mathrm{s}=1,2,3,4$ and $\mathrm{r}<\mathrm{s}$ ) is an index set over the latent Poisson variates that create the covariances between the observed count data for the airports. The observable data is characterized as a 4-variate Poisson denoted $Y_{i} \sim$

\footnotetext{
${ }^{5}$ The survey instrument is in an appendix available from the authors. ${ }^{6} \mathrm{PHL}$ management and consumers may not have the same definition of the relevant market. Unfortunately we were compelled to accept management's definition of the market for the purpose of generating the phone call database. Their definition was based on drive time and the sense that they could effectively market their product to those households within one hour of the airport. Basically they had a market retention mentality.

${ }^{7}$ In effect the data set is a general stratified sample. Ben-Akiva and Lerman [24] address this issue and the estimators for slopes in a choice model. The punch line is that in choice models the estimators are consistent for all except the constant term.
}

$\operatorname{MP}\left(\theta_{i}\right)$ for the $\mathrm{i}=1,2, \ldots, \mathrm{n}$ observations and $\theta_{i}=$ $\left\{\theta_{i j} ; j \in S\right\}$ is the vector of parameters for the $\mathrm{i}^{\text {th }}$ observation. The parameters for the $\mathrm{i}^{\text {th }}$ observation in turn depend on a vector of independent variables $z_{i j}, j=1,2, \ldots$, $\mathrm{p}_{\mathrm{j}}$ through a univariate Poisson regression structure

$$
\log \left(\theta_{i j}\right)=z_{i j}^{T^{\prime}} \beta_{j} i=1,2, \ldots, n \text { and } j \in S
$$

and $\beta_{j}^{T}=\left(\beta_{j 1}, \beta_{j 2}, \ldots, \beta_{j p_{j}}\right)$ is a $\mathrm{p}_{\mathrm{j}}$ vector of regression coefficients.

The unknown parameters are estimated by an expectation maximization (EM) algorithm [4]. The EM algorithm is used for finding maximum likelihood estimates of probabilistic model parameters where the underlying data are unobservable. EM alternates between performing an expectation step and a maximization step. In the expectation step an empirical expectation of the likelihood is computed as though, based on current estimates of the parameters, the latent variables had been observed. In this step the current values for the $\hat{\theta}_{i}(z, \beta)=$ $\left\{\hat{\theta}_{i j} ; j \in S\right\}$ are used to construct expected values for the $x_{i}=\left\{x_{i j} ; j \in S\right\}$, given the current guess for the parameters what must have been the values taken by the latent variables contingent on the $\mathrm{Y}$ observations, and the empirical likelihood is computed. In the maximization step the maximum likelihood parameter estimates $\hat{\theta}_{i}(z, \beta)=\left\{\hat{\theta}_{i j} ; j \in S\right\}$ are recalculated on the basis of the expected likelihood computed in the expectation step; given the guesses for the elements of the latent variables in the previous step, how should the parameters by revised in order to maximize the empirical likelihood. In the present context this amounts to fitting univariate Poisson models using the conditional expectations of the estimation step. The open question is the modeling of the rate parameters.

\section{The Data}

In April and May 2000 a phone survey ${ }^{5}$ was conducted on behalf of the management of the Philadelphia International Airport. Approximately 5000 households in a market region defined by the management of the Philadelphia International Airport ${ }^{6}$ (shown in Figure 1) were contacted regarding their participation in the survey about travel outside the region and modal choice. The phone contacts were selected from one of two sub-populations; those who had previously expressed an interest in travel and those from the general population ${ }^{7}$. Those who had flown out of Philadelphia International Airport are over-represented in the sample. The resulting final sample had 1100 usable responses, of which 827 had traveled out of the region and 627 had flown out of 
Table 1. (a) Airport size 2000; (b) Frequency of usage correlations 2000

\begin{tabular}{|c|c|c|c|c|c|c|c|c|c|}
\hline \multicolumn{6}{|c|}{ (a) } & \multicolumn{4}{|c|}{ (b) } \\
\hline & Airlines & $\begin{array}{l}\text { Nonstop } \\
\text { destinations }\end{array}$ & $\begin{array}{l}\text { Plane } \\
\text { movements }\end{array}$ & $\begin{array}{l}\text { Total pas- } \\
\text { sengers } \\
\text { (enplane- } \\
\text { ments }+ \\
\text { deplane- } \\
\text { ments) }\end{array}$ & $\begin{array}{l}\text { Automobile } \\
\text { Parking } \\
\text { Spaces }\end{array}$ & & BWI & JFK & Newark \\
\hline BWI & 22 & 61 & 275,000 & $19,500,000$ & 12,000 & PHL & .2779 & .2471 & .3537 \\
\hline JFK & 57 & 387 & 339,597 & $31,000,000$ & 12,300 & BWI & & .1347 & .0481 \\
\hline EWR & 37 & 543 & 455,000 & $33,000,000$ & 17,000 & JFK & & & .0806 \\
\hline PHL & 26 & 111 & 484,000 & $24,900,000$ & 6,500 & $\begin{array}{l}\text { All cc } \\
\text { the } 1^{\circ}\end{array}$ & $\begin{array}{l}\text { ations } \\
\text { vel. }\end{array}$ & signifi & tly greater than zero at \\
\hline
\end{tabular}

Table 2. Descriptive statistics

\begin{tabular}{|c|c|c|c|c|}
\hline & Variable & Coding & Mean or Frequency \\
\hline \multirow{4}{*}{\multicolumn{2}{|c|}{ Dependent Variables }} & Flown from PHL & \multirow{4}{*}{ Counts for flights from airport in prior year. } & 3.2648 \\
\hline & & Flown from BWI & & .4812 \\
\hline & & Flown from JFK & & .2140 \\
\hline & & Flown from EWR & & .5574 \\
\hline \multirow{6}{*}{\multicolumn{2}{|c|}{ Indirect Utility Arguments }} & Income & Continuous, dollars. & $\$ 67,308.59$ \\
\hline & & Distance to PHL & \multirow[t]{4}{*}{ Continuous, miles. } & 26.38 \\
\hline & & Distance to BWI & & 99.41 \\
\hline & & Distance to JFK & & 90.98 \\
\hline & & Distance to EWR & & 76.63 \\
\hline & & PHL Premium & $\begin{array}{l}\text { Continuous, Cost of flight from PHL over } \\
\text { flight from other airport, dollars. }\end{array}$ & $\$ 546.34$ \\
\hline \multirow{2}{*}{\multicolumn{2}{|c|}{ Demographics }} & Age & Years & 48.98 \\
\hline & & Gender & $\begin{array}{l}\text { Female }=1 \\
\text { Male } \quad=0\end{array}$ & 307 Male \\
\hline \multirow{15}{*}{$\begin{array}{l}\text { Tastes and } \\
\text { Preferences }\end{array}$} & \multirow{4}{*}{$\begin{array}{l}\text { Purpose of Trips } \\
\text { is Mostly Pleas- } \\
\text { ure }\end{array}$} & PHL & \multirow{4}{*}{$\begin{array}{l}\text { Pleasure }=1 \\
\text { Otherwise }=0\end{array}$} & 346 \\
\hline & & BWI & & 73 \\
\hline & & JFK & & 61 \\
\hline & & EWR & & 98 \\
\hline & \multirow[t]{4}{*}{ Destination } & PHL & \multirow{4}{*}{$\begin{array}{l}\text { Destination is domestic }=1 \\
\text { Otherwise }=0\end{array}$} & 443 \\
\hline & & BWI & & 132 \\
\hline & & JFK & & 62 \\
\hline & & EWR & & 90 \\
\hline & \multicolumn{2}{|c|}{ Will consider use of PHL in Future } & \multirow{2}{*}{$\begin{array}{l}\text { Yes }=1 \\
\text { No }=0\end{array}$} & 527 \\
\hline & \multicolumn{2}{|c|}{ Will consider use of BWI, JFK, EWR in future } & & 155 \\
\hline & \multirow{5}{*}{$\begin{array}{l}\text { Importance of } \\
\text { airport attribute } \\
\text { in choice }\end{array}$} & Choice of Carrier & \multirow{5}{*}{$\begin{array}{l}\text { Important or Very Important }=1 \\
\text { Otherwise }=0\end{array}$} & 492 \\
\hline & & $\begin{array}{l}\text { Distance from home to } \\
\text { airport }\end{array}$ & & 468 \\
\hline & & International flights & & 360 \\
\hline & & Non-stop flights & & 508 \\
\hline & & Low ticket prices & & 546 \\
\hline
\end{tabular}

one or more of the major airports in the region ${ }^{8}$.

Travelers in the Philadelphia region have an abundance of commercial airports from which to choose. At the southern edge of the city is Philadelphia International Airport (PHL). Further to the south are Wilmington and Baltimore-Washington International (BWI). To the northwest is Lehigh Valley International Airport. To the west is Reading Airport. To the east is Atlantic City Airport. To the north are Newark Airport (EWR) and
John F. Kennedy International Airport (JFK). For the purposes of this paper we have modeled only the intensity of usage of the four major airports: BWI, JFK, EWR, and $\mathrm{PHL}^{9}$. The sizes of the four airports are indicated by the data in Table 1, Part A. The size rank order depends on the variable in question, although BWI is the smallest of the four by every standard except available parking spaces.

Based on the sample data, and relying on the simple 


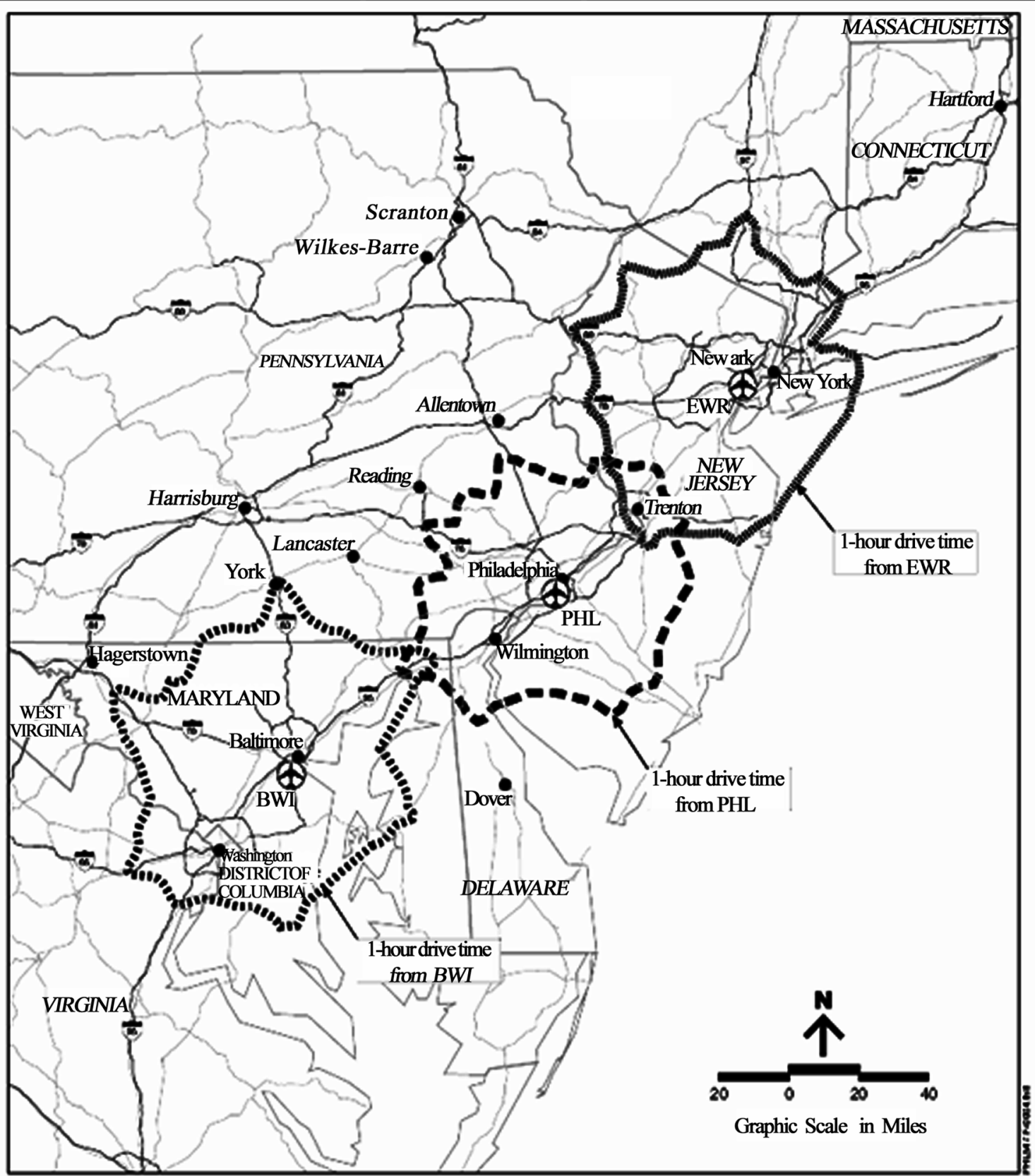

LEGEND

- Interstate Highway

OtherMajorHighway

Figure 1

AIRPORT SERVICE REGIONS

AirlineCompetition Plan

Philadelphia intemational Airport

August 2000

Figure 1. Philadelphia international airport market area 
Table 3. Univariate poisson ${ }^{1,2}$

\begin{tabular}{|c|c|c|c|c|}
\hline Variable & PHL & BWI & JFK & EWR \\
\hline Intercept & $\begin{array}{l}-4.6502^{*} \\
(30.24)\end{array}$ & $\begin{array}{l}-2.7635 \\
(1.60)\end{array}$ & $\begin{array}{l}1.7209 \\
(0.27)\end{array}$ & $\begin{array}{l}-0.7667 \\
(0.15)\end{array}$ \\
\hline Income & $\begin{array}{l}0.0959^{*} \\
(90.09) \\
\end{array}$ & $\begin{array}{l}-0.0186 \\
(0.37)\end{array}$ & $\begin{array}{l}-0.0154 \\
(0.18)\end{array}$ & $\begin{array}{l}0.1589^{*} \\
(41.36)\end{array}$ \\
\hline Distance to PHL & $\begin{array}{l}-0.0048^{*} \\
(3.39)\end{array}$ & $\begin{array}{l}.0030 \\
(0.17)\end{array}$ & $\begin{array}{l}.0102 \\
(1.01)\end{array}$ & $\begin{array}{l}.0344^{*} \\
(24.29)\end{array}$ \\
\hline Distance to BWI & $\begin{array}{l}.0126^{*} \\
(7.73)\end{array}$ & $\begin{array}{l}-0.0192 * \\
(3.02)\end{array}$ & $\begin{array}{l}-0.0255 \\
(1.95)\end{array}$ & $\begin{array}{l}-0.0173 \\
(2.26)\end{array}$ \\
\hline Distance to JFK & $\begin{array}{l}.0010 \\
(0.02) \\
\end{array}$ & $\begin{array}{l}.0209 \\
(0.87) \\
\end{array}$ & $\begin{array}{l}-0.0297 \\
(1.04) \\
\end{array}$ & $\begin{array}{l}-0.0288^{*} \\
(3.08) \\
\end{array}$ \\
\hline Distance to EWR & $\begin{array}{l}.0171^{*} \\
(8.05)\end{array}$ & $\begin{array}{l}-0.0277 \\
(2.54)\end{array}$ & $\begin{array}{l}.0086 \\
(0.14)\end{array}$ & $\begin{array}{l}-0.0032 \\
(0.05)\end{array}$ \\
\hline PHL Cost Premium & $\begin{array}{l}.0004^{*} \\
(52.29)\end{array}$ & $\begin{array}{l}.0003^{*} \\
(6.20)\end{array}$ & $\begin{array}{l}.0002 \\
(0.84)\end{array}$ & $\begin{array}{l}.0005^{*} \\
(23.02)\end{array}$ \\
\hline Purpose of trips & $\begin{array}{l}-0.8375^{*} \\
(352.93)\end{array}$ & $\begin{array}{l}-0.0555 \\
(0.24)\end{array}$ & $\begin{array}{l}.8321^{*} \\
(11.62)\end{array}$ & $\begin{array}{l}.3719^{*} \\
(10.92)\end{array}$ \\
\hline Age & $\begin{array}{l}.0756^{*} \\
(67.94)\end{array}$ & $\begin{array}{l}.0894 * \\
(9.50)\end{array}$ & $\begin{array}{l}.0215 \\
(0.42)\end{array}$ & $\begin{array}{l}.0937 * \\
(15.64)\end{array}$ \\
\hline Age2 & $\begin{array}{l}-0.0009^{*} \\
(85.24)\end{array}$ & $\begin{array}{l}-0.0010^{*} \\
(9.01)\end{array}$ & $\begin{array}{l}-0.0004 \\
(1.08)\end{array}$ & $\begin{array}{l}-0.0011^{*} \\
(17.91)\end{array}$ \\
\hline Gender & $\begin{array}{l}-0.2045^{*} \\
(25.56)\end{array}$ & $\begin{array}{l}-0.0192 \\
(0.03)\end{array}$ & $\begin{array}{l}-0.2715^{*} \\
(2.78)\end{array}$ & $\begin{array}{l}-0.2753^{*} \\
(7.95)\end{array}$ \\
\hline Carrier of Choice & $\begin{array}{l}.0385 \\
(.68)\end{array}$ & $\begin{array}{l}-0.0599 \\
(0.28)\end{array}$ & $\begin{array}{l}-0.1538 \\
(0.72)\end{array}$ & $\begin{array}{l}.0088 \\
(0.01)\end{array}$ \\
\hline Distance to Airport & $\begin{array}{l}-0.2617 * \\
(37.06)\end{array}$ & $\begin{array}{l}-0.2917^{*} \\
(7.68)\end{array}$ & $\begin{array}{l}-0.0189 \\
(0.01)\end{array}$ & $\begin{array}{l}-0.1745 \\
(2.50)\end{array}$ \\
\hline $\begin{array}{ll}\text { International } & \text { Flight } \\
\text { Available } & \\
\end{array}$ & $\begin{array}{l}.2899^{*} \\
(48.90) \\
\end{array}$ & $\begin{array}{l}.2000^{*} \\
(3.48) \\
\end{array}$ & $\begin{array}{l}.6214^{*} \\
(9.64) \\
\end{array}$ & $\begin{array}{l}.5235^{*} \\
(30.15) \\
\end{array}$ \\
\hline Non-stop flights available & $\begin{array}{l}.1625^{*} \\
(8.86)\end{array}$ & $\begin{array}{l}-0.3894 * \\
(10.18)\end{array}$ & $\begin{array}{l}.1561 \\
(0.60)\end{array}$ & $\begin{array}{l}-0.4021^{*} \\
(11.83)\end{array}$ \\
\hline Low ticket prices & $\begin{array}{l}.4746^{*} \\
(57.05) \\
\end{array}$ & $\begin{array}{l}.2682 \\
(1.88) \\
\end{array}$ & $\begin{array}{l}.2268 \\
(0.86) \\
\end{array}$ & $\begin{array}{l}.1414 \\
(0.93) \\
\end{array}$ \\
\hline $\begin{array}{l}\text { Will consider airport in } \\
\text { future }\end{array}$ & $\begin{array}{l}.7042^{*} \\
(118.90)\end{array}$ & $\begin{array}{l}.4221 * \\
(12.33)\end{array}$ & $\begin{array}{l}.0403 \\
(.05)\end{array}$ & $\begin{array}{l}.9112^{*} \\
(73.47)\end{array}$ \\
\hline Domestic Destination $^{3}$ & $\begin{array}{l}.8282^{*} \\
(220.12)\end{array}$ & $\begin{array}{l}3.7195^{*} \\
(364.78)\end{array}$ & $\begin{array}{l}2.0284^{*} \\
(66.68)\end{array}$ & $\begin{array}{l}1.2101^{*} \\
(106.00)\end{array}$ \\
\hline Goodness of Fit ${ }^{4}$ & 3.2074 & 0.5975 & 0.6053 & 1.4583 \\
\hline Overdispersion $^{5}$ & 44173.58 & 384.99 & 158.20 & 305.79 \\
\hline \multicolumn{5}{|c|}{ 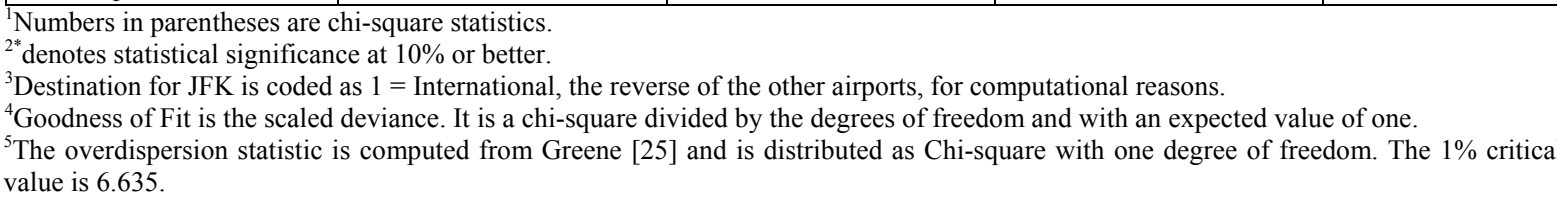 } \\
\hline
\end{tabular}

proportions shown in Table 2, EWR and BWI were the most significant competitors for PHL. EWR and JFK are significant competitors only for international travel. Business travelers are much more likely to shift among

${ }^{8}$ The model is fit to the 827 households that traveled outside the region; the 273 households that did not travel were excluded from the sample. Excluding households that did not fly because they did not travel may introduce overdispersion. Over dispersion test were performed and the null was not rejected. Any attempt to include these households would have resulted in missing observations excluding them anyway.

${ }^{9} \mathrm{BWI}$ is south of PHL on US I-95. EWR is north of PHL on US I-95, and JFK is located on the south shore of Long Island, about forty minutes east of EWR.

${ }^{10}$ Convenience for the business traveler goes beyond access to the airport to include considerations of departure time, connections, etc. the regional airports than are those traveling for pleasure $^{10}$. This is corroborated by the simple frequency of use correlations between airports in Part B of Table 1.

Although the survey was quite comprehensive in its topical coverage, only demographic data, frequency of travel from other airports, preferences regarding airport attributes, and comparison price shopping were used in the empirical model ${ }^{11}$. Descriptive statistics for these variables appear in Table 2. The dependent variables for the model are the frequencies with which individuals in the respondent's household had flown from one of the major airports in the previous year. Of PHL's three rival airports, the greatest proportion reported having flown out of EWR. Given its relative inaccessibility it is not 
Table 4. (a) Multivariate poisson estimates ${ }^{1}$ : Own parameters; (b) Multivariate poisson estimates ${ }^{1}$ : Cross parameters

\begin{tabular}{|c|c|c|c|c|c|c|c|c|c|c|c|c|}
\hline \multicolumn{13}{|c|}{ (a) } \\
\hline Variable & \multicolumn{3}{|c|}{ PHL } & \multicolumn{3}{|c|}{ BWI } & \multicolumn{3}{|c|}{ JFK } & \multicolumn{3}{|c|}{ EWR } \\
\hline & Intercept Only & $\begin{array}{l}\text { Only } \\
\text { Own } \\
\text { Covari- } \\
\text { ates }\end{array}$ & $\begin{array}{l}\text { Own and } \\
\text { Cross-covariates }\end{array}$ & $\begin{array}{l}\text { Inter- } \\
\text { cept } \\
\text { Only }\end{array}$ & $\begin{array}{c}\text { Only } \\
\text { Own } \\
\text { Covari- } \\
\text { ates }\end{array}$ & $\begin{array}{c}\text { Own and } \\
\text { Cross- } \\
\text { covariates }\end{array}$ & $\begin{array}{l}\text { Inter- } \\
\text { cept } \\
\text { Only }\end{array}$ & \begin{tabular}{|c|}
$\begin{array}{c}\text { Only } \\
\text { Own } \\
\text { Covari- } \\
\text { ates }\end{array}$ \\
\end{tabular} & $\begin{array}{c}\text { Own and } \\
\text { Cross-covariates }\end{array}$ & $\begin{array}{c}\text { Inter- } \\
\text { cept } \\
\text { Only }\end{array}$ & $\begin{array}{c}\text { Only } \\
\text { Own } \\
\text { Covari- } \\
\text { ates }\end{array}$ & $\begin{array}{c}\text { Own and } \\
\text { Cross- } \\
\text { covariates }\end{array}$ \\
\hline Intercept & $\begin{array}{l}-0.9926 \\
(0.0707)\end{array}$ & $\begin{array}{l}-4.8811 \\
(0.8761) \\
\end{array}$ & $\begin{array}{r}-4.1653 \\
(0.8737) \\
\end{array}$ & \begin{tabular}{|l|}
-1.4863 \\
$(0.1034)$ \\
\end{tabular} & \begin{tabular}{|l|}
-2.6713 \\
$(2.2946)$ \\
\end{tabular} & \begin{tabular}{|l|}
-0.4840 \\
$(2.3720)$ \\
\end{tabular} & \begin{tabular}{|l|}
-2.8730 \\
$(0.0755)$ \\
\end{tabular} & \begin{tabular}{|c|}
1.2358 \\
$(3.4014)$ \\
\end{tabular} & $\begin{array}{r}-1.1430 \\
(4.2394) \\
\end{array}$ & \begin{tabular}{|l|}
-1.1690 \\
$(0.3187)$ \\
\end{tabular} & \begin{tabular}{|r|} 
\\
4.2767 \\
$(2.9462)$ \\
\end{tabular} & $\begin{array}{c}6.1828 \\
(2.3599) \\
\end{array}$ \\
\hline Income & & $\begin{array}{c}0.1009 \\
(0.0420) \\
\end{array}$ & $\begin{array}{c}0.0873 \\
(0.0103) \\
\end{array}$ & & $\begin{array}{l}-0.0397 \\
(0.0323)\end{array}$ & \begin{tabular}{|r|}
-0.1101 \\
$(0.0338)$ \\
\end{tabular} & & $\begin{array}{l}-0.0175 \\
(0.0373)\end{array}$ & $\begin{array}{c}0.0277 \\
(0.0424)\end{array}$ & & \begin{tabular}{|c|}
0.1682 \\
$(0.0317)$
\end{tabular} & $\begin{array}{c}0.1630 \\
(0.0284) \\
\end{array}$ \\
\hline $\begin{array}{l}\text { Distance to } \\
\text { PHL }\end{array}$ & & $\begin{array}{l}-0.0051 \\
(0.0027)\end{array}$ & $\begin{array}{l}-0.0053 \\
(0.0027)\end{array}$ & & $\begin{array}{l}0.0040 \\
.0076)\end{array}$ & \begin{tabular}{|c|}
0.0056 \\
$(0.0080)$
\end{tabular} & & $\begin{array}{c}0.0103 \\
(0.0104)\end{array}$ & $\begin{array}{l}-0.0049 \\
(0.0128)\end{array}$ & & $\begin{array}{c}0.0454 \\
(0.0115)\end{array}$ & $\begin{array}{c}0.0569 \\
(0.0079)\end{array}$ \\
\hline $\begin{array}{c}\text { Distance to } \\
\text { BWI }\end{array}$ & & $\begin{array}{c}0.0129 \\
(0.0047)\end{array}$ & $\begin{array}{c}0.0104 \\
(0.0047)\end{array}$ & & \begin{tabular}{|c|}
-0.0230 \\
$(0.0115)$
\end{tabular} & \begin{tabular}{|l|}
-0.0269 \\
$(0.0122)$ \\
\end{tabular} & & $\begin{array}{l}-0.0227 \\
(0.0186)\end{array}$ & $\begin{array}{c}-0.0078 \\
(0.0234) \\
\end{array}$ & & $\begin{array}{c}0.0017 \\
(0.0187) \\
\end{array}$ & $\begin{array}{c}-0.0608 \\
(0.0142)\end{array}$ \\
\hline $\begin{array}{l}\text { Distance to } \\
\text { JFK }\end{array}$ & & $\begin{array}{l}-0.0048 \\
(0.0083) \\
\end{array}$ & $\begin{array}{c}0.0039 \\
(0.0083) \\
\end{array}$ & & $\begin{array}{l}0.0083 \\
(.0232) \\
\end{array}$ & \begin{tabular}{|c|}
0.0241 \\
$(0.0240)$ \\
\end{tabular} & & $\begin{array}{l}-0.0265 \\
(0 . .0294) \\
\end{array}$ & $\begin{array}{c}0.0023 \\
(0.0379) \\
\end{array}$ & & \begin{tabular}{|c|}
-0.0346 \\
$(0.0218)$ \\
\end{tabular} & $\begin{array}{l}-0.0281 \\
(0.0203) \\
\end{array}$ \\
\hline $\begin{array}{c}\text { Distance to } \\
\text { EWR }\end{array}$ & & $\begin{array}{c}0.0232 \\
(0.0062)\end{array}$ & $\begin{array}{c}0.0122 \\
(0.0063)\end{array}$ & & \begin{tabular}{|l|}
-0.0202 \\
$(0.0181)$
\end{tabular} & \begin{tabular}{|l|}
-0.0359 \\
$(0.0188)$ \\
\end{tabular} & & $\begin{array}{c}0.0074 \\
(0.0234) \\
\end{array}$ & $\begin{array}{c}-0.0108 \\
(0.0328)\end{array}$ & & $\begin{array}{c}0.0032 \\
(0.0174) \\
\end{array}$ & $\begin{array}{l}-0.0479 \\
(0.0220)\end{array}$ \\
\hline $\begin{array}{l}\text { PHLCost } \\
\text { Prmium }\end{array}$ & & $\begin{array}{c}0.0004 \\
(0.0104)\end{array}$ & $\begin{array}{c}0.0004 \\
(0.0001)\end{array}$ & & $\begin{array}{c}0.0004 \\
(0.0001)\end{array}$ & \begin{tabular}{|c|}
0.0005 \\
$(0.0001)$
\end{tabular} & & $\begin{array}{c}0.0002 \\
(0.0002)\end{array}$ & $\begin{array}{c}0.0000 \\
(0.0001)\end{array}$ & & $\begin{array}{c}0.0004 \\
(0.0001)\end{array}$ & $\begin{array}{c}0.0006 \\
(0.0001)\end{array}$ \\
\hline Purpose of trips & & \begin{tabular}{|l|}
-0.8264 \\
$(0.0096)$
\end{tabular} & $\begin{array}{l}-0.8274 \\
(0.0455)\end{array}$ & & \begin{tabular}{|c|}
-0.1651 \\
$(0.1159)$
\end{tabular} & \begin{tabular}{|l|}
-0.2360 \\
$(0.1221)$
\end{tabular} & & $\begin{array}{c}0.7357 \\
(0.2444) \\
\end{array}$ & $\begin{array}{c}3.2784 \\
(0.2804)\end{array}$ & & $\begin{array}{c}0.1482 \\
(0.1399)\end{array}$ & $\begin{array}{c}0.5176 \\
(0.1218)\end{array}$ \\
\hline Age & & $\begin{array}{l}0.0785 \\
(0.0001)\end{array}$ & $\begin{array}{c}0.0701 \\
(0.0093)\end{array}$ & & $\begin{array}{c}0.0801 \\
(0.0308)\end{array}$ & \begin{tabular}{|c|}
0.0363 \\
$(0.0286)$
\end{tabular} & & $\begin{array}{c}0.0184 \\
(0.0336)\end{array}$ & $\begin{array}{c}0.0102 \\
(0.0397)\end{array}$ & & $\begin{array}{c}0.0871 \\
(0.0335)\end{array}$ & $\begin{array}{c}0.0720 \\
(0.0270)\end{array}$ \\
\hline Age2 & & \begin{tabular}{|l|}
-0.0009 \\
$(0.0001)$
\end{tabular} & $\begin{array}{l}-0.0008 \\
(0.0001)\end{array}$ & & \begin{tabular}{|c|}
-0.0008 \\
$(0.0003)$
\end{tabular} & \begin{tabular}{|c|}
-0.0004 \\
$(0.0003)$
\end{tabular} & & $\begin{array}{l}-0.0003 \\
(0.0003)\end{array}$ & $\begin{array}{c}-0.0003 \\
(0.0004)\end{array}$ & & \begin{tabular}{|l|}
-0.0009 \\
$(0.0003)$
\end{tabular} & $\begin{array}{c}-0.0008 \\
(0.0003)\end{array}$ \\
\hline Gender & & $\begin{array}{l}-0.1899 \\
(0.0412) \\
\end{array}$ & $\begin{array}{c}-0.2313 \\
(0.0413) \\
\end{array}$ & & \begin{tabular}{|c|}
-0.0056 \\
$(0.1096)$
\end{tabular} & \begin{tabular}{|c|}
0.0535 \\
$(0.1145)$ \\
\end{tabular} & & $\begin{array}{r}-0.2484 \\
(0.1656) \\
\end{array}$ & $\begin{array}{r}-0.4986 \\
(0.2057) \\
\end{array}$ & & \begin{tabular}{|l|}
-0.2114 \\
$(0.1303)$ \\
\end{tabular} & $\begin{array}{r}-0.2178 \\
(0.1104) \\
\end{array}$ \\
\hline $\begin{array}{l}\text { Airline of } \\
\text { Choice }\end{array}$ & & $\begin{array}{c}0.0226 \\
(0.0448)\end{array}$ & $\begin{array}{c}0.0491 \\
(0.0478)\end{array}$ & & \begin{tabular}{|c|}
-0.1131 \\
$(0.1176)$
\end{tabular} & \begin{tabular}{|c|}
0.1133 \\
$(0.1279)$
\end{tabular} & & $\begin{array}{l}-0.1296 \\
(0.1846)\end{array}$ & $\begin{array}{c}0.1674 \\
(0.2436)\end{array}$ & & \begin{tabular}{|l|}
-0.0146 \\
$(0.1366)$
\end{tabular} & $\begin{array}{c}0.2332 \\
(0.1239)\end{array}$ \\
\hline $\begin{array}{l}\text { Distance to } \\
\text { Airport }\end{array}$ & & $\begin{array}{l}-0.2390 \\
(0.0429) \\
\end{array}$ & $\begin{array}{l}-0.2308 \\
(0.0440)\end{array}$ & & $\begin{array}{l}-0.3580 \\
(0.1096) \\
\end{array}$ & \begin{tabular}{|l|}
-0.4093 \\
$(0.1154)$ \\
\end{tabular} & & \begin{tabular}{|l|}
-0.0528 \\
$(0.1843)$ \\
\end{tabular} & $\begin{array}{c}0.2641 \\
(0.2223) \\
\end{array}$ & & \begin{tabular}{|l|}
-0.0890 \\
$(0.1582)$ \\
\end{tabular} & $\begin{array}{l}-0.1549 \\
(0.1239) \\
\end{array}$ \\
\hline Intern. Flight & & $\begin{array}{l}0.3071 \\
(0.0583)\end{array}$ & $\begin{array}{c}0.2617 \\
(0.0424)\end{array}$ & & $\begin{array}{c}0.1345 \\
(0.1120)\end{array}$ & \begin{tabular}{|c|}
0.1085 \\
$(0.1191)$
\end{tabular} & & $\begin{array}{c}0.6645 \\
(0.2057) \\
\end{array}$ & $\begin{array}{c}0.5913 \\
(0.2338)\end{array}$ & & $\begin{array}{c}1.0758 \\
(0.1579) \\
\end{array}$ & $\begin{array}{c}0.4809 \\
(0.1287)\end{array}$ \\
\hline $\begin{array}{l}\text { Non-stop } \\
\text { flights }\end{array}$ & & \begin{tabular}{|c|}
0.2567 \\
$(0.0642)$
\end{tabular} & $\begin{array}{c}0.1804 \\
(0.0560)\end{array}$ & & \begin{tabular}{|c|}
-0.5003 \\
$(0.1265)$
\end{tabular} & \begin{tabular}{|l|}
-0.3728 \\
$(0.1326)$
\end{tabular} & & $\begin{array}{c}0.1326 \\
(0.2035)\end{array}$ & $\begin{array}{l}-0.4717 \\
(0.2378)\end{array}$ & & \begin{tabular}{|l|}
-0.1917 \\
$(0.1599)$
\end{tabular} & $\begin{array}{l}-0.6086 \\
(0.1256)\end{array}$ \\
\hline Low Price & & $\begin{array}{c}0.4132 \\
(0.0669)\end{array}$ & $\begin{array}{c}0.5078 \\
(0.0651)\end{array}$ & & $\begin{array}{c}0.2530 \\
(0.2036)\end{array}$ & \begin{tabular}{|c|}
0.0289 \\
$(0.2065)$
\end{tabular} & & $\begin{array}{c}0.2009 \\
(0.2461)\end{array}$ & $\begin{array}{c}0.4567 \\
(0.3392)\end{array}$ & & \begin{tabular}{|l|}
-0.5590 \\
$(0.1793)$ \\
\end{tabular} & $\begin{array}{c}0.3051 \\
(0.1683)\end{array}$ \\
\hline $\begin{array}{l}\text { Airport in } \\
\text { Future }\end{array}$ & & $\begin{array}{l}0.6895 \\
(0.0462)\end{array}$ & $\begin{array}{c}0.7072 \\
(0.0666)\end{array}$ & & $\begin{array}{c}0.4571 \\
(0.1281)\end{array}$ & \begin{tabular}{|c|}
0.7316 \\
$(0.1334)$
\end{tabular} & & $\begin{array}{c}0.0375 \\
(0.1880)\end{array}$ & $\begin{array}{c}0.0884 \\
(0.2089)\end{array}$ & & $\begin{array}{c}1.4036 \\
(0.1499)\end{array}$ & $\begin{array}{c}1.2993 \\
(0.1195)\end{array}$ \\
\hline $\begin{array}{c}\text { Domestic Des- } \\
\text { tination }\end{array}$ & & $\begin{array}{c}.8867 \\
(0.0587)\end{array}$ & $\begin{array}{c}0.7911 \\
(0.0569) \\
\end{array}$ & & $\begin{array}{c}4.9473 \\
(0.3146)\end{array}$ & \begin{tabular}{|c|}
4.0638 \\
$(0.2289)$
\end{tabular} & & $\begin{array}{c}2.1647 \\
(0.2497)\end{array}$ & $\begin{array}{l}-0.2652 \\
(0.2765)\end{array}$ & & $\begin{array}{c}1.5270 \\
(0.1448)\end{array}$ & $\begin{array}{c}0.6469 \\
(0.1323)\end{array}$ \\
\hline Goodness of Fit 7 & 77.68 & 3.81 & 3.26 & 2.81 & \begin{tabular}{|l|}
0.67 \\
\end{tabular} & \begin{tabular}{|l|}
0.47 \\
\end{tabular} & 1.22 & 0.95 & 0.78 & 2.98 & 1.49 & 1.19 \\
\hline Over-dispersion 7 & 72.8494 & 17.8356 & 12.3120 & 16.4139 & \begin{tabular}{l|l|}
9 & 0.2512 \\
\end{tabular} & 0.0517 & 1.7510 & 1.4743 & 0.8327 & 51.0083 & 6.7871 & 8.1977 \\
\hline
\end{tabular}

surprising that JFK was used the least by those participating in the study.

The phone survey was conducted during both daytime and evening hours, still women appear to be over-represented in the sample and the average age of respondents. The respondents' age seems to be somewhat higher than the general population ${ }^{12}$. Any biases introduced by this are ameliorated in part because the questions referred not just to the individual but also to other members of the household. A second ameliorating reason is that those making travel decisions are older than the general population.

To capture the respondent's preferences we questioned them about the importance of different attributes of the airports they choose for their departures: choice of carrier, distance to the airport, availability of international flights, availability of non-stop flights, and presence of a low fare carrier. In response to each named attribute the respondent had to rate the importance of the attribute on a scale from 0 to 5 . A 0 meant that the attribute was not at all important in the choice of airport, while a 5 meant that the attribute was extremely important. The categorical variables were recoded as dummy variables in which the dummy took a value of one if the attribute or characteristic was important or extremely important, and zero otherwise. Even with 827 observations this was necessary in order to preserve degrees of freedom since each of five categorical variables would have needed five dummies in each of four equations for a total of 100 coefficients to be estimated in the 'own' latent variable parameters and thirty more in the 'cross' latent variable parameters. 


\begin{tabular}{|c|c|c|c|c|c|c|}
\hline \multicolumn{7}{|c|}{ (b) } \\
\hline & $\begin{array}{c}\beta_{12} \\
\text { PHL-BWI } \\
\end{array}$ & $\begin{array}{c}\beta_{13} \\
\text { PHL-JFK } \\
\end{array}$ & $\begin{array}{c}\beta_{14} \\
\text { PHL-EWR } \\
\end{array}$ & $\begin{array}{c}\beta_{23} \\
\text { BWI-JFK } \\
\end{array}$ & $\begin{array}{c}\beta_{24} \\
\text { BWI-EWR } \\
\end{array}$ & $\begin{array}{c}\beta_{34} \\
\text { JFK-EWR }\end{array}$ \\
\hline & \multicolumn{6}{|c|}{$\begin{array}{c}\text { Intercept Only } \\
\end{array}$} \\
\hline Constant & $\begin{array}{l}-1.4203 \\
(0.8889) \\
\end{array}$ & $\begin{array}{l}-2.1834 \\
(0.1913) \\
\end{array}$ & $\begin{array}{l}-1.5498 \\
(0.0200) \\
\end{array}$ & $\begin{array}{l}-6.4847 \\
(0.0728)\end{array}$ & $\begin{array}{l}-4.4334 \\
(0.1463)\end{array}$ & $\begin{array}{l}-3.4124 \\
(0.0624)\end{array}$ \\
\hline & \multicolumn{6}{|c|}{ Own Covariates Only } \\
\hline Constant & $\begin{array}{l}-3.3126 \\
(0.1819)\end{array}$ & $\begin{array}{l}-11.1798 \\
(8.2713)\end{array}$ & $\begin{array}{l}-1.6524 \\
(0.0794)\end{array}$ & $\begin{array}{l}-5.6071 \\
(10.3666)\end{array}$ & $\begin{array}{l}-11.9811 \\
(0.5727)\end{array}$ & $\begin{array}{l}-4.8901 \\
(0.4009)\end{array}$ \\
\hline & \multicolumn{6}{|c|}{ Own- and Cross-covariates } \\
\hline Constant & $\begin{array}{c}-158.9580 \\
(70.0804)\end{array}$ & $\begin{array}{l}-186.1933 \\
(65.0043)\end{array}$ & $\begin{array}{l}-35.7531 \\
(11.0068)\end{array}$ & $\begin{array}{l}-168.7721 \\
(57.3307)\end{array}$ & $\begin{array}{l}-98.3382 \\
(116.3201)\end{array}$ & $\begin{array}{l}-48.4551 \\
(20.3832)\end{array}$ \\
\hline Gender & $\begin{array}{c}0.6821 \\
(3.2583)\end{array}$ & $\begin{array}{l}9.0643 \\
(3.7696)\end{array}$ & $\begin{array}{l}-0.1828 \\
(0.4854)\end{array}$ & $\begin{array}{r}-12.1547 \\
(4.6281)\end{array}$ & $\begin{array}{l}-5.7411 \\
(8.1581)\end{array}$ & $\begin{array}{l}3.3350 \\
(2.2894)\end{array}$ \\
\hline Income & $\begin{array}{c}2.4149 \\
(0.9592)\end{array}$ & $\begin{array}{l}0.7534 \\
(1.1107)\end{array}$ & $\begin{array}{l}0.5740 \\
(0.1370)\end{array}$ & $\begin{array}{l}3.2353 \\
(0.9174)\end{array}$ & $\begin{array}{l}-1.6019 \\
(1.8122)\end{array}$ & $\begin{array}{l}-1.1716 \\
(0.5320)\end{array}$ \\
\hline Age & $\begin{array}{c}3.4240 \\
(2.1153)\end{array}$ & $\begin{array}{l}4.3864 \\
(1.7690)\end{array}$ & $\begin{array}{l}0.4212 \\
(0.1264)\end{array}$ & $\begin{array}{l}2.5693 \\
(1.7027)\end{array}$ & $\begin{array}{l}-0.4105 \\
(3.6229)\end{array}$ & $\begin{array}{l}1.7731 \\
(0.7870)\end{array}$ \\
\hline Age2 & $\begin{array}{r}-0.0342 \\
(0.0210) \\
\end{array}$ & $\begin{array}{c}-0.0291 \\
(0.0143) \\
\end{array}$ & $\begin{array}{c}-0.0038 \\
(0.0012) \\
\end{array}$ & $\begin{array}{l}-0.0339 \\
(0.0177) \\
\end{array}$ & $\begin{array}{l}0.0066 \\
(0.0427) \\
\end{array}$ & $\begin{array}{c}-0.0296 \\
(0.0115) \\
\end{array}$ \\
\hline Carrier & $\begin{array}{l}17.2770 \\
(9.7328) \\
\end{array}$ & $\begin{array}{l}-0.5263 \\
(2.6063)\end{array}$ & $\begin{array}{c}-0.3163 \\
(0.4169)\end{array}$ & $\begin{array}{l}-5.8861 \\
(11.2654)\end{array}$ & $\begin{array}{l}-30.2447 \\
(5.4843)\end{array}$ & $\begin{array}{l}2.5751 \\
(1.9926)\end{array}$ \\
\hline Distance & $\begin{array}{c}7.5194 \\
(4.7410)\end{array}$ & $\begin{array}{l}-5.3075 \\
(2.3233)\end{array}$ & $\begin{array}{l}-1.3789 \\
(0.4175)\end{array}$ & $\begin{array}{l}6.8751 \\
(3.5287)\end{array}$ & $\begin{array}{l}9.8577 \\
(11.0292)\end{array}$ & $\begin{array}{l}1.1548 \\
(2.1540)\end{array}$ \\
\hline $\begin{array}{l}\text { Interna- } \\
\text { tional }\end{array}$ & $\begin{array}{c}0.1996 \\
(2.9954)\end{array}$ & $\begin{array}{l}-9.0871 \\
(3.8296)\end{array}$ & $\begin{array}{l}0.3889 \\
(0.4060)\end{array}$ & $\begin{array}{l}3.9001 \\
(4.0220)\end{array}$ & $\begin{array}{l}11.9829 \\
(3.1542)\end{array}$ & $\begin{array}{l}3.8812 \\
(3.3086)\end{array}$ \\
\hline Non-stop & $\begin{array}{c}-10.8234 \\
(5.9471)\end{array}$ & $\begin{array}{l}10.4281 \\
(5.2275)\end{array}$ & $\begin{array}{l}2.4725 \\
(0.7993)\end{array}$ & $\begin{array}{l}4.3507 \\
(7.0232)\end{array}$ & $\begin{array}{l}-1.6884 \\
(8.1904)\end{array}$ & $\begin{array}{l}4.0210 \\
(2.9817)\end{array}$ \\
\hline Pricing & $\begin{array}{c}5.6050 \\
(3.7408) \\
\end{array}$ & $\begin{array}{l}-10.6328 \\
(5.6392)\end{array}$ & $\begin{array}{l}-3.3539 \\
(0.9096) \\
\end{array}$ & $\begin{array}{l}-9.417 \\
(12.9732)\end{array}$ & $\begin{array}{l}12.5169 \\
(8.0006)\end{array}$ & $\begin{array}{l}3.7280 \\
(3.6626)\end{array}$ \\
\hline $\begin{array}{ll}\text { Will } & \text { Use } \\
\text { PHL } & \\
\end{array}$ & $\begin{array}{c}7.6172 \\
(4.4773) \\
\end{array}$ & $\begin{array}{c}-4.2938 \\
(5.9367) \\
\end{array}$ & $\begin{array}{l}-4.3224 \\
(0.9744) \\
\end{array}$ & -- & -- & -- \\
\hline $\begin{array}{ll}\text { Will } & \text { Use } \\
\text { Other } & \end{array}$ & $\begin{array}{c}-16.3339 \\
(6.7274)\end{array}$ & $\begin{array}{l}-13.4868 \\
(7.9894)\end{array}$ & $\begin{array}{l}-6.5853 \\
(1.3802)\end{array}$ & $\begin{array}{l}-8.8263 \\
(5.4286)\end{array}$ & $\begin{array}{l}-10.7623 \\
(4.7005)\end{array}$ & $\begin{array}{l}-5.1143 \\
(3.7945)\end{array}$ \\
\hline $\begin{array}{l}\text { PHL } \\
\text { mium }\end{array}$ & $\begin{array}{l}-0.0067 \\
(0.0046)\end{array}$ & $\begin{array}{l}0.0004 \\
(0.0049)\end{array}$ & $\begin{array}{l}0.0020 \\
(0.0006)\end{array}$ & -- & -- & -- \\
\hline $\begin{array}{l}\text { Distance to } \\
\mathrm{i}\end{array}$ & $\begin{array}{l}-0.2101 \\
(0.3202)\end{array}$ & $\begin{array}{l}0.3084 \\
(0.1157)\end{array}$ & $\begin{array}{c}-0.0014 \\
(0.0160)\end{array}$ & $\begin{array}{l}0.2039 \\
(0.2592)\end{array}$ & $\begin{array}{l}0.1501 \\
(0.3319)\end{array}$ & $\begin{array}{l}0.0499 \\
(0.1969)\end{array}$ \\
\hline $\begin{array}{l}\text { Destination } \\
\text { from i }\end{array}$ & $\begin{array}{c}16.2027 \\
(10.2507)\end{array}$ & $\begin{array}{c}-1.6024 \\
(3.6469)\end{array}$ & $\begin{array}{c}-0.7071 \\
(0.9399)\end{array}$ & $\begin{array}{l}7.1347 \\
(15.5945)\end{array}$ & $\begin{array}{l}35.4171 \\
(4.6455)\end{array}$ & $\begin{array}{l}15.7171 \\
(4.9331)\end{array}$ \\
\hline $\begin{array}{l}\text { Distance to } \\
\mathrm{j}\end{array}$ & $\begin{array}{c}0.0583 \\
(0.1192)\end{array}$ & $\begin{array}{l}-0.2442 \\
(0.1237)\end{array}$ & $\begin{array}{l}0.1003 \\
(0.0222)\end{array}$ & $\begin{array}{l}0.7135 \\
(0.1322)\end{array}$ & $\begin{array}{l}0.71345 \\
(0.3797)\end{array}$ & $\begin{array}{c}-0.0265 \\
(0.1809)\end{array}$ \\
\hline $\begin{array}{l}\text { Destination } \\
\text { from } j\end{array}$ & $\begin{array}{c}8.5510 \\
(4.0695)\end{array}$ & $\begin{array}{l}44.2165 \\
(14.4379)\end{array}$ & $\begin{array}{l}17.2567 \\
(9.7092)\end{array}$ & $\begin{array}{c}20.4702 \\
(6.4014)\end{array}$ & $\begin{array}{l}-14.7535 \\
(8.6005)\end{array}$ & $\begin{array}{l}6.5796 \\
(2.8247)\end{array}$ \\
\hline Purpose i & $\begin{array}{l}-9.4457 \\
(5.2732)\end{array}$ & $\begin{array}{c}13.7023 \\
(4.9055)\end{array}$ & $\begin{array}{l}3.2956 \\
(0.9270)\end{array}$ & $\begin{array}{l}2.7957 \\
(5.0255)\end{array}$ & $\begin{array}{l}-3.0041 \\
(6.8273)\end{array}$ & $\begin{array}{l}-11.0594 \\
(4.3178)\end{array}$ \\
\hline Purpose $\mathrm{j}$ & $\begin{array}{c}5.5829 \\
(2.3648)\end{array}$ & $\begin{array}{l}-24.4502 \\
(9.4837)\end{array}$ & $\begin{array}{c}-1.8782 \\
(0.6858)\end{array}$ & $\begin{array}{l}-11.7110 \\
(6.6219)\end{array}$ & $\begin{array}{l}14.3912 \\
(6.0686)\end{array}$ & $\begin{array}{l}-1.4067 \\
(2.4231)\end{array}$ \\
\hline
\end{tabular}

Only the presence of international flights was of little or no importance to PHL users. This is somewhat surprising given PHL's notoriously poor international service at that time. A surprising $20 \%$ of respondents reported that they had compared a fare out of PHL with fares available at other airports. As a follow-up they were also asked about the fare difference in that comparison. For the 165 travelers that made the comparison the average fare premium was $\$ 546.34 .^{13}$

\section{Empirical Results}

The index function that is used here is a mix of indirect utility arguments, such as price premium for flying from
PHL, actual distance to the airport and income ${ }^{14}$, and tastes and preferences, such as the assessment that using the carrier of choice is important. The survey results included data on the respondents' age and gender ${ }^{15}$.

The signs on age and gender are indeterminate a priori, although it is reasonable to expect that frequency of flying and age is a nonlinear relationship. The marginal effect of an increase in income on the probability of using a more distant airport could be negative or positive. As an individual's income rises she finds the opportunity cost of increased travel time to a more distant airport to be a disincentive to using that airport ${ }^{16}$. On the other hand service and fare might overcome that (dis)incentive. 
Table 5. Marginal effects on mean number of trips

\begin{tabular}{|l|l|l|l|l|l|l|l|l|}
\hline & \multicolumn{4}{|c}{ Univariate } & \multicolumn{1}{c|}{ Multivariate } \\
\hline & \multicolumn{1}{|c|}{ PHL } & \multicolumn{1}{|c|}{ BWI } & JFK & EWR & PHL & \multicolumn{1}{|c|}{ BWI } & JFK & EWR \\
\hline DPHL & -0.012 & 0.0003 & 0.0011 & 0.0095 & -0.0155 & 0.0002 & -0.0002 & 0.0114 \\
\hline DBWI & 0.0314 & -0.0018 & -0.0027 & -0.0048 & 0.0303 & -0.0010 & -0.0003 & -0.0122 \\
\hline DJFK & 0.0025 & 0.0020 & -0.0032 & -0.0079 & 0.0114 & 0.0009 & 0.0001 & -0.0056 \\
\hline DEWR & 0.0426 & -0.0027 & 0.0009 & -0.0009 & 0.0356 & -0.0013 & -0.0004 & -0.0010 \\
\hline Income & 0.2388 & -0.0073 & -0.0016 & 0.0438 & 0.2545 & -0.0039 & 0.0001 & 0.0328 \\
\hline Cost Premium & 0.0010 & 0.0001 & 0.00002 & 0.0001 & 0.0012 & 0.00002 & 0.0000 & .0001 \\
\hline Age & -0.0313 & -0.0033 & -0.0019 & -0.0039 & -0.0241 & -0.0001 & -0.0007 & -0.0013 \\
\hline Carrier & 0.0955 & -0.0058 & -0.0167 & 0.0002 & 0.9183 & 0.0041 & 0.0062 & 0.0460 \\
\hline International & 0.7382 & 0.0196 & 0.0705 & 0.1510 & 0.5652 & 0.0039 & 0.0236 & 0.1007 \\
\hline Non-stop & 0.3979 & -0.0396 & 0.0165 & -0.1166 & 0.3749 & -0.0142 & -0.0190 & -0.1329 \\
\hline Low cost & 1.1057 & 0.0249 & 0.0235 & 0.0381 & 1.0019 & 0.0010 & 0.0162 \\
\hline Distance & -0.6642 & -0.0294 & -0.0021 & -0.0487 & -0.0674 & -0.0287 & -0.0127 & 0.0586 \\
\hline Purpose & -2.0045 & -0.0052 & 0.1310 & 0.1188 & -2.3191 & -0.0146 & 0.9475 & -0.0311 \\
\hline Domestic & 2.0526 & 2.1500 & 0.6083 & 0.5686 & 1.2798 & 2.0302 & 0.286 \\
\hline Will Use & 1.622 & 0.0469 & 0.0494 & 0.3455 & 1.9068 & 0.0638 & .0043 & 1.7834 \\
\hline Gender & -0.5239 & -0.0018 & -0.0397 & -0.1039 & -0.6965 & 0.0036 & -0.0079 & -0.0447 \\
\hline
\end{tabular}

The indirect utility arguments include whether the respondent had obtained the price of a comparable flight from an airport other than Philadelphia and what the price difference turned out to be. One would expect that a consumer's price research would induce them to use the flight departing from the cheaper airport.

Tastes and preferences are modeled from a sequence of questions regarding factors that the traveler finds important in choice of airport as well as the purpose and destinations of trips taken. The survey ${ }^{17}$ asked for an ordered response to eight questions regarding airport attributes, although only five are used here ${ }^{18}$. Survey participants could rank an attribute of an airport and its services from 0 to 5 ; a response of 0 indicated that the factor was not at all important, a response of 5 indicated that the factor was extremely important in the decision making process. Table 2 provides the variables and cor-

\footnotetext{
${ }^{11}$ Household size was included in the survey, but was not significant in any of the model specifications. If the dependent variable had been the number of tickets purchased for flights from each airport then household size would have been essential. If the trip or journey is the dependent variable then the number of individuals making the trip is irrelevant. If, say BWI, is the cheaper and closer airport for one member of the family then it is still cheaper and closer when they travel as a group.]

${ }^{12}$ Only respondents indicating that they were over 18 were included in the survey. The survey was conducted only among landline telephone subscribers. In 2004 the percent of the population with 'cell phone

only' service was 6.3 percent in metropolitan areas [26].

${ }^{13}$ Or $\$ 109$ when averaged over the entire sample.

${ }^{14}$ At the time of the phone survey the respondent's 3 digit telephone exchange was captured. Using the airport phone exchanges it was then possible to retrieve the distance from the respondent to each of the airports from a commercially available database [27]. The same database was used to code income as the median for residents of the particular telephone exchange. As part of the survey participants were asked to respond categorically to a question about their household income. Of course not all respondents answered that question. The correlation between our income construct and the categorical responses was 0.87 .
}

responding descriptive statistics.

If ability to choose a particular airline or fly an international carrier is important then one would expect that the respondent would be more likely to have flown out of JFK, all other things equal, given its much wider choice of carriers (See Table 1). People for whom distance to the airport is an important consideration would be less likely to have flown out of JFK. If finding a nonstop flight is extremely important then the respondent should be more likely to have flown out of EWR. The folk wisdom at the time of the survey was that because USAir had dominated PHL for so long it had the ability to charge higher fares. There was no similar carrier dominance in the other three airports. Therefore, if price is an extremely important consideration then a respondent should be less likely to have flown out of PHL in the preceding year.

Both univariate, Table 3, and multivariate, Table 4, Poisson models were fit to the data ${ }^{19}$. For both sets of results measures of goodness of fit and over dispersion are included. Three specifications of the multivariate model for each airport are reported in Table 4. The first specification assumed homogeneity across all respondents and involved estimating the $10 \mathrm{x} 1$ vector $\theta$ of Equation (5) as though all coefficients except the intercept on the covariates of Equation (7) were zero. The second specification assumed heterogeneity in the $\theta_{\mathrm{i}}(\mathrm{i}=1,2,3,4)$ but homogeneity in the covariance terms, $\theta_{\mathrm{ij}}(\mathrm{i}, \mathrm{j}=1,2,3,4$ and $\mathrm{i}<\mathrm{j}$ ). In the third specification all of the $\theta$ were treated as heterogeneous across the respondents.

In comparing the univariate and multivariate results there is essentially no change in the sign pattern on the covariate coefficients or which coefficients are significant $^{20}$. The goodness of fit statistics ${ }^{21}$ are roughly comparable for the two models. The biggest difference arises in the over dispersion statistics ${ }^{22}$. For the unvaried model the null hypothesis of no over dispersion is rejected for 
each of the four airports ${ }^{23}$. With the exception of the intercepts only specification for PHL the null of no over dispersion is never rejected for the multivariate model. It would appear that the latent variable specification allowing for covariance between airport usage eliminates the over dispersion problem apparent in the univariate models. To put it somewhat differently, the univariate model is not correctly specified. Finally, the $\theta_{\mathrm{ij}}$ terms, the count covariance latent variables, are statistically different from zero in nine out of twelve instances in the intercepts only and own covariates only versions of the multivariate Poisson models.

Since particular covariates appear in both the coefficient vector of the own-latent variables and the crosslatent variables it is more useful to consider the incremental effects of the covariates on the mean response. The results for both the univariate and multivariate models are summarized in Table 5: Marginal effects on mean number of trips ${ }^{24}$. In the case of continuous covariates the marginal effects are derivatives. In the case of the discrete covariates the model is evaluated for the two values of the dummy variable and the difference computed. All derivatives and differences are evaluated at the means of the covariates.

The effect of distance from a given airport on the frequency of choice of that airport has the expected negative sign for PHL, BWI and EWR. The sign for JFK is positive due to the dominant cross effect between JFK and BWI in part B or Table 4; as one gets further from either one of them one uses one or the other more often. A greater distance from any of the other three airports will

\footnotetext{
${ }^{15}$ Gender of respondent may be serving as a proxy for many different aspects of the airport choice process. Including it in the models has a small effect on statistical efficiency, but excluding a relevant variable introduces bias.

${ }^{16}$ The geographically more distant airport does not always mean greater travel time. Traffic congestion, high speed rail links, etc. may result in less travel time to the more distant airport. For the airports in the region under study greater distance translates to greater travel time.

17The survey instrument is available from the authors.

${ }^{18}$ The omitted questions include ease of parking, ease of check-in, and presence of public transit. For any given airport the variability in categorical rating was quite narrow so the variables were omitted from the analysis.

${ }^{19}$ The univariate model was fit using PROC GENMOD in SAS. The multivariate EM estimation algorithm was programmed in MATLAB. The starting values for the MATLAB program were taken from the univariate results. The convergence criterion for the EM algorithm was a percent change in the empirical log likelihood of less than $1 \times 10^{-12}$.

${ }^{20}$ Similar sign pattern, statistical significance and coefficient magnitude should not be confused with goodness of fit. The goodness of fit statistics are higher in the multivariate specification. Even if the covariates of the covariance structure were not significant for a specific sample in the multivariate model it would not reduce the importance of the approach.

${ }^{21}$ The goodness of fit statistic is the scaled deviance (SAS 9.0).

${ }^{22}$ The over dispersion statistic is the lagrange multiplier statistic from Greene [25].

${ }^{23}$ It is worth noting that the over dispersion in the univariate models leads to overstating the significance of the individual coefficients.
}

increase the frequency of flights from PHL. As a respondent gets further from PHL or JFK, her mean usage of BWI increases. However, as they become more distant from EWR their mean usage of BWI decreases. This is attributable to the geography of the region and cross effects. If one is on the north side of PHL and moves further from EWR then one must be getting closer to PHL, hence there is a shift from BWI to PHL. If one is to the south of PHL and one gets further from EWR then one must be getting closer to BWI and further from PHL. It may be that the attributes other than distance overwhelm the distance effect for BWI. Mean usage of JFK is decreasing in distance from any of the other three airports. This is easy to understand for EWR since a greater distance from EWR means that one is more distant from JFK. If one is more distant from BWI than one must be closer to JFK, but the total distance remains great and PHL is relatively more attractive as a choice. The relative attraction of PHL overwhelms any gain that might be attributed to being further away from PHL, hence the negative sign. The negative sign on distance from JFK in the EWR mean is explained by the fact that being further from JFK means being further from EWR and closer to PHL. Similarly, being further from BWI moves one closer to EWR, but the proximity effect of PHL is overwhelming.

Higher income results in an increase in the mean use of PHL, JFK and EWR, although the effect on use of JFK is numerically very much smaller than that for either PHL or EWR. The sign on income is negative for BWI. As it happens, mean income increases with distance from BWI so there is a confounding income-distance effect for the use of BWI.

At the time of the survey the folk wisdom was that as a consequence of USAir's dominance of PHL that fares out of PHL were higher than the other airports and that travelers would use the other airports to get lower fares. In Table 5 the effect of a greater PHL premium is to increase usage of the other airports. Unfortunately, there is also a positive effect on the mean usage of PHL. This may be due in part to the fact that the effects of distance overwhelm any cost advantage to flying from another airport [28]. This could be thought of as a barrier to customer mobility that results in limit pricing by the carrier: US Airways might charge a premium with the expectation that customers will not defect to another airport.

The coefficients on covariates age and its square are respectively positive and negative, although their aggregate effect on mean use is negative for all four airports. The gender effect is that women fly less often than men from all airports but BWI. If the purpose of one's trips was mostly for pleasure then one would use JFK more frequently and the others less frequently, on average. At the time of the survey PHL's choice of carrier, international, and non-stop service was poor. When traveling for 
pleasure, and time in transit has a lower opportunity cost, one might be more inclined to use a more inconvenient airport in order to get the desired service attributes. If destination of the trips was domestic then one was more likely to use PHL, BWI and EWR. Since domestic destination for JFK was coded as the reverse of the other three airports the sign must be switched ${ }^{25}$. Thus, if the destination of the trips was international then travelers increased their mean use of JFK.

Six taste and preference questions were included in the specifications: Importance of choice of carrier, importance of international flights, importance of availability of non-stop flights, importance of low fare carriers, importance of distance to the airport, and willingness to use the airport again ${ }^{26}$. In magnitude, the marginal effect of international flight availability on mean usage of PHL is much greater than that for the other airports due to the size of the cross covariates in part B of Table 5; at the time of the survey PHL had the reputation of being very inconvenient for international travelers. Apparently, if an international flight is available at all three airports then a consumer in the PHL market area will be more likely to travel from PHL. Apparently the management at PHL had at least a visceral understanding of this. Since the time of the survey PHL has constructed a new international terminal in order to address the needs of overseas travelers in its market. When the availability of non stop flights is an important consideration travelers use PHL more often and are less likely to use the other airports as often. Table 1 shows that two airports had better non-stop service than PHL, and at that time PHL was not a hub for any of its carri-

\footnotetext{
${ }^{24}$ There are no significance tests indicated in Table 5 since they are unnecessary. One or more of the coefficients on each variable for a given airport is significant so the corresponding effect on the rate parameter will also be significant. The Poisson rate parameter is recovered from the tabled numbers by Equation (7). The mapping from the estimated coefficients to the rate parameter is an affine transformation. Affine transformations preserve ordering and distance. Also, the usual test statistics are scale invariant. Hence, if a significant relationship exists before the transformation it will be significant after the transformation. Greene [25] addresses the same sort of question.

${ }^{25}$ Among those in the sample who had flown from JFK the proportion using that airport to get international service was much greater than those using the airport for domestic service, the reverse of the other airports. As it happened, this switch also resulted in the EM algorithm converging more rapidly.

${ }^{26}$ Willingness to use the airport again is a taste and preference variable to the extent that it reflects changing proclivity on the basis of prior experience. The neoclassical model assumes stable preferences, but in reality preferences do change in the aftermath of experience.

${ }^{27}$ Although USAir dominated the airport by any measure, PHL was not its east coast hub. Its hub remained in Pittsburgh even though it had more traffic in and out of PHL.

${ }^{28}$ Southwest Airlines. The addition of new terminals, another discount carrier and more international service has resulted in PHL being the second fastest growing airport in the world, behind only Beijing.

${ }^{29} \mathrm{~A}$ response rate of $22 \%$ is typical for a phone survey that employs no special devices to increase response rates and rates of cooperation [29].
}

$\mathrm{ers}^{27}$. The importance of the presence of a low cost carrier also had its greatest impact on PHL. Again, this is not surprising since at the time of the survey Airtran, a low cost carrier, had only recently come to PHL. Since the time of the survey PHL has built a short commuter runway, built another domestic service terminal, and added a second low cost carrier ${ }^{28}$. When distance to the airport is an important consideration the effect for all four airports is to reduce the mean number of trips, consistent with the findings for actual distance. Finally, a willingness to use the given airport again will increase the mean use of any of the airports.

\section{Conclusions}

A multivariate Poisson specification was used to analyze data on the choice of airport from a phone survey of the Philadelphia International Airport (PHL) market. The survey polled nearly 5000 homes to generate a usable sample of 827 respondents that had traveled outside the region $^{29}$. In airport choice studies the respondents are intercepted in an airport and queried about the choice that has brought them to that location instead of others in the choice set. The corresponding appropriate analytical methodology is multinomial logit or probit. The phone survey used here asked respondents to report on all of their air travel in the prior year. Hence, for each respondent there was a count of the number of times she had flown from each of the four airports in the region. Since the count data represents the results of choices made repeatedly over many short time periods it is in principle Poisson distributed.

Since each respondent was flying from among four major airports the correct specification is multivariate Poisson. The multivariate Poisson, which does not have a closed form, can be recast as a latent variables problem that results in marginal distributions for correlated Poisson variates. The parameters in the multivariate Poisson model were estimated using an expectation maximization algorithm.

An airport's own-distance had the expected negative impact on mean usage of the airport, although the cross effects were somewhat mixed. Mean usage was found to be increasing in income for PHL, but was decreasing for the other airports, reflecting the increasing value of respondents' time as their income rises. On balance the quadratic form in respondent's age resulted in less frequent flights among older respondents. A rising fare premium for using PHL resulted in higher mean use for Newark (EWR), Baltimore (BWI) and New York (JFK). The fare premium was also positive for use of PHL, reflecting that market power of PHL's dominant carrier at the time of the survey. If the destination of flights is domestic (international) then the result is to increase usage of PHL, BWI and EWR (JFK). Except for JFK, if the 
purpose of travel is mostly pleasure then it results in more travel from JFK and less from the other three airports. The availability of a low cost carrier would result in more frequent travel.

Since the time of the survey the entry of a new low cost carrier and the construction of a new international arrivals terminal have caused PHL usage to increase dramatically. It experienced a 10.5 percent increase in passengers in 2005 alone and a 28 percent increase since 2003. In terms of aircraft activity PHL is now the ninth largest in the world [30].

In summary, given the results of the model, it appears that at the time of the study airlines at Philadelphia International Airport made a profit maximizing decision to take advantage of their regional monopoly. Their prices were high enough to extract monopoly rent while losing only small numbers of passengers to lower cost carriers at other airports. Hence outmigration of potential passengers is not a significant constraint on monopoly power at airports. These results also tend to support smaller geographic market definitions and perhaps even the practice of price discrimination. The entry of Southwest into Philadelphia International Airport may have reclaimed some marginal travelers that had been going to the competing airports, but the biggest impact will be on fare competition among airlines already serving PHL.

\section{REFERENCES}

[1] Hess, Stephane, and Polak, J., "Mixed logit modeling of airport choice in multi-airport regions," Journal of Air Transport Management, Vol. 11, No. 2, pp. 59-68, 2005.

[2] Hess, Stephane, and Polak, J., "Airport, airline and access-mode choice in the san francisco bay area airports," Papers in Regional Science, Forthcoming, 2006.

[3] Blackstone, E., Buck, A. J., and Hakim, S., "Determinants of airport choice in a multi-airport region," Atlantic Economic Journal, Vol. 34, No. 3, pp. 3-326, September 2006.

[4] Karlis, D., and Meligkotsidou, L., "Multivariate poisson regression with covariance structure," Statistics and Computing, Vol. 15, pp. 255-265, 2005.

[5] Ashford, N. and Benchemam, M., "Passengers' choice of airport: An application of the multinomial logit model," Transportation Research Record 1147, National Research Council, Washington, D.C., 1987.

[6] Caves, R. E., Ndoh, N. N., and Pitfield, D. E., "Route choice modeling applied to the choice between mature airports and emergent airports in their shadow," Paper presented at the $31^{\text {st }}$ RSA European Congress, Lisbon, Portugal, August 27-30, 1991.

[7] Thompson, A. and Caves, R. E., "The projected market share for a new small airport in the North of England," Regional Studies, Vol. 27, No. 2, pp. 137-147, 1993.

[8] Harvey, G., "Airport choice in a multiple airport region,"
Transportation Research, Vol. 21A, No. 6, pp. 439-449, 1987.

[9] Basar, G. and Bhat, C., "A parameterized consideration set model for airport choice: An application to the san francisco bay area," Transportation Research Part B: Methodological, Vol. 38, No. 10, pp. 9-904, December 2004.

[10] Hess, S., "An analysis of airport-choice behavior using the mixed multinomial logit model," Center for Transport Studies, Imperial College, London, 2004, http://www.ersa.org/ersaconfs/ersa04/PDF/61.pdf.

[11] Ishii, J., Jun, S., and VanDender, K., "Air travel choices in multi-airport markets," 2005.

[12] Pels, E., Nijkamp, P., and Rietveld, P., "Access to and competition between airports: A case study for the san francisco bay area," Transportation Research Part A: Policy and Practice, Vol. 37, No. 1, pp. 71-83, January 2003.

[13] Windle, R. and Dresner, M., "Airport choice in a multi-airport region," Journal of Transportation Engineering, Vol. 121, No. 4, pp. 332-338, July-August, 1995.

[14] Gardiner, J., Humphreys, I., and Ison, S., "Freighter operators' choice of airport: A three-stage process," Transport Reviews, Vol. 25, No. 1, pp. 85-102, January 2005.

[15] Gosling, G. D., "Southern California association of governments regional airport demand model: Literature review," Project \#5437, June 2003.

[16] Belden, T. and Ginsberg, T., "A sign of US Airways' health," Philadelphia Inquirer, pp. A1 and A4, November 16,2006

[17] Morrison, S. A., "Airline service," in L. L. Deutsch, Industry Studies, $3^{\text {rd }}$ Edition, M. E. Sharpe, Armonk, NY, pp. 151-152, 2002.

[18] McFadden, D., "Econometric analysis of qualitative response models," In Z. Griliches and M. Intriligator, eds., Handbook of Econometrics, North Holland, Amsterdam, Vol. 2, 1984.

[19] Maddala, G. and Flores-Lagunes, A., "Qualitative response models," in B. Baltagi, ed., A Companion to Theoretical Econometrics, Blackwell, Oxford, 2001.

[20] Ross, S. M., "Introduction to probability models," Academic Press, New York, pp. 174-175, 1980.

[21] Aitchison, J. and Ho, C. H., "The multivariate poissonlog normal distribution," Biometrika, Vol. 76, No. 4, pp. 643-653, 1989.

[22] Terza, J. V. and Wilson, P. W., "Analyzing frequencies of several types of events: A mixed multinomial poisson approach," The Review of Economics and Statistics, Vol. 72, No. 1, 108-115, 1990.

[23] Shonkwiler, J. S. and Englin, J., "Welfare losses due to livestock grazing on public lands: A count data systemwide treatment," American Journal of Agricultural Economics, Vol. 87, No. 2, pp. 302-313, 2005.

[24] Ben-Akiva, M. and Lerman, S. R., Discrete Choice Analysis: Theory and Application to Travel Demand, pp. 235-239, the MIT Press, Cambridge, MA, 1985.

[25] Greene, W., Econometric Analysis, 5th Edition, Prentice 
Hall, New York, pp. 743-744, 2003.

[26] Blumberg, S. J., Luke, J. V., and Cynamon, M. L., "Telephone coverage and health survey estimates: evaluating the need for concern about wireless substitution," American Journal of Public Health, Vol. 96, No. 5, pp. 926-931, May 2006.

[27] Jay Computer Services, $9594208^{\text {th }}$ Street West, Lakeville, MN 55044, http://nt.jcsm.com or whttp://www.jcsm.com, last accessed on 11/09/2006.

[28] Shapiro, H., "The frugal flier: Getting the best buy on an airline ticket means considering much more than the fare," Philadelphia Inquirer, pp. N06, March 28, 2004.

[29] deLeeuw, E. and Hox, J. J., "I am not selling anything: 29 experiments in telephone introductions," International Journal of Public Opinion Research, Vol. 16, No. 4, pp. 464-473, 2004.

[30] PHL (Philadelphia International Airport), "2005 numbers show Philadelphia international airport is now the $9^{\text {th }}$ busiest airport for aircraft operations," 2006, http://www.phl.org/news060228.html. 